\title{
Land Use, Landscape and Sustainability: Examples from Montesinho
}

\section{J. Castro}

The traditional and multifunctional landscapes of Montesinho Natural Park (PNM), with their typical complexes of agro-, silvo- and pastoral components, changed thoroughly during past decades. Historical, social, economic and cultural factors, such as poor communications, biophysical events, and direct contact with nature in everyday life should be taken into account to explain its present land use pattern.

The current land use patterns are based in an ancestral arrangement of factors resulting from a combination of two main parameters: water availability and village proximity, both of them highly dependent of the topographic circumstances. As a result, four main land use groups must be considered: vegetable gardens and orchards near village streams margins, mainly over Fluvisols; meadows along the streams, also over Fluvisols; open cereal fields around the village, frequently over Dystric Cambisols and Leptosols; and more or less wooded open land outside this agricultural matrix, on Umbric Leptosols (IPB/ICN, 2006). The last one, the open woodland matrix, is the largest component of PNM landscape. Essentially, it is an export ecosystem: shrubs, firewood, pasture, but also, rock outcrops, honey, etc. In contrast, the vegetable gardens and orchards benefit greatly from human and animal labor, manure and water, in order to produce the seasonal fresh food to complement the inhabitants' diet, which is mainly based on cereals and meat. The meadows are, or were, essentially a "power" ecosystem feeding cattle used to plough fields. The open cereal fields ultimately provide bread, the basis of human life.

J. Castro $(\bowtie)$

Instituto Politécnico de Bragança, Escola Superior Agrária, Apartado 1172

5301-855 Bragança, Portugal

e-mail: mzecast@ipb.pt 


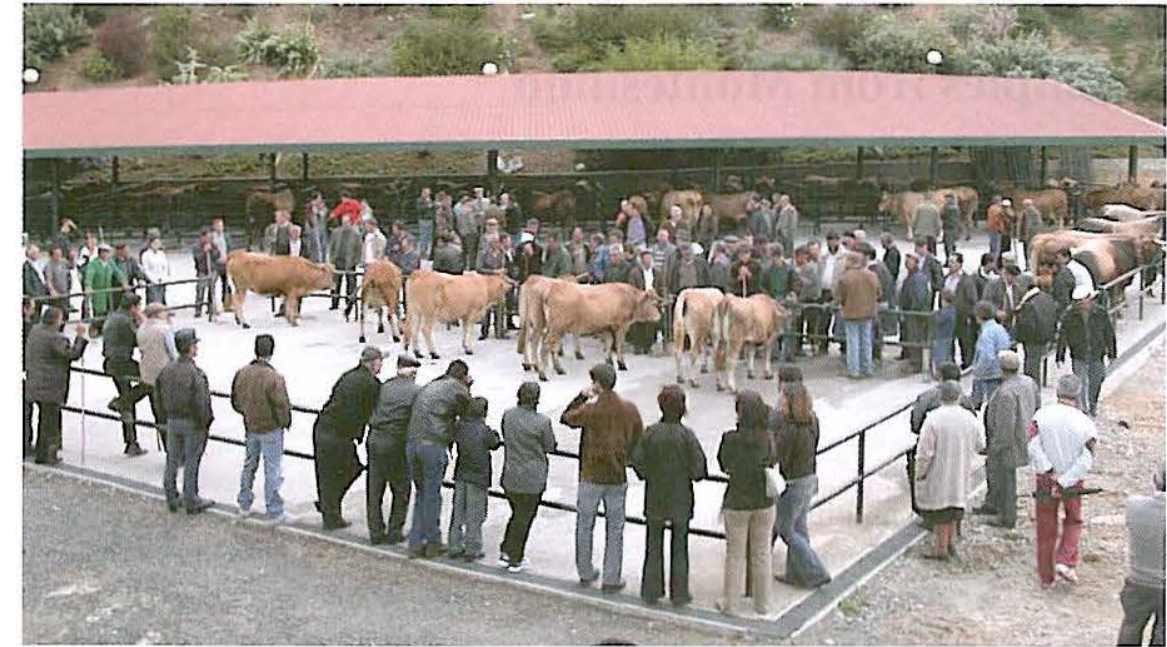

"Mirandesa" - a good example of traditional systems and active promotion of products specimens of this autochtonous cattle breed at contest in Vinhais (photo by F. de Sousa)

Until a few decades ago, the PNM economy was based on agriculture, cattle rearing and several less important activities. Most of the population engaged in traditional stock farming involving few animals. The largely subsistence-based household economy was boosted with income from the sale of animals, eggs, butte and handicrafts. Other important economic activities were smuggling and forestry in Montesinho (Pardo-de-Santayana et al., 2007).

In contrast with many other Mediterranean mountain situations, the modern PNM landscapes are still living; their complex farming systems simultaneously support a multitude of functions other than agricultural production, such as support for recreation, amenity, cultural identity, and preservation of natural resources and environmental quality. The modern landscapes still include the mosaic of meadows, forests, rivers and high mountain vegetation growing on varied geological materi als and soils and the predominant natural vegetation consists of oak forest species, broom scrubland and heath. Many fields once used to grow cereals (for bread), pulses, turnip and potatoes now provide grazing for cattle. Agriculture plays only a minor role and new economic activities, such as rural tourism, are increasingly important (IPB/ICN, 2006)

The current and general process of abandonment seems to favour natural ecosystems, promoting the development of habitats of pristine character such as the oak riparian and chestnuts woods. Field cultivation is not expanding, and planting exotic forest species is not acceptable under current nature conservation regulations. On the other hand burning and grazing are essential process to maintain semi-natural habitats such as scrublands of heather and gorse, as well as the meadows. However burning and grazing must be done in the traditional way, at the right frequency, extension and intensity. If not, they will favour erosion, degradation processes and consequent soil loss. Illegal sand and gravel extraction in rivers and localized foci of water pollution are not frequent but their occurrence prejudices riparian ecosystems
The great challenge for the near future will be to manage and balance human pressure on natural and semi-natural habitats. On the one hand landscape must be recognized as a dynamic reality that man can only adjust but not rebuild. On the other hand, human processes, such as those involved in PNM landscape dynamics, are associated with rural livelihood and ways of life that cannot be controlled but only be recognized and understood.

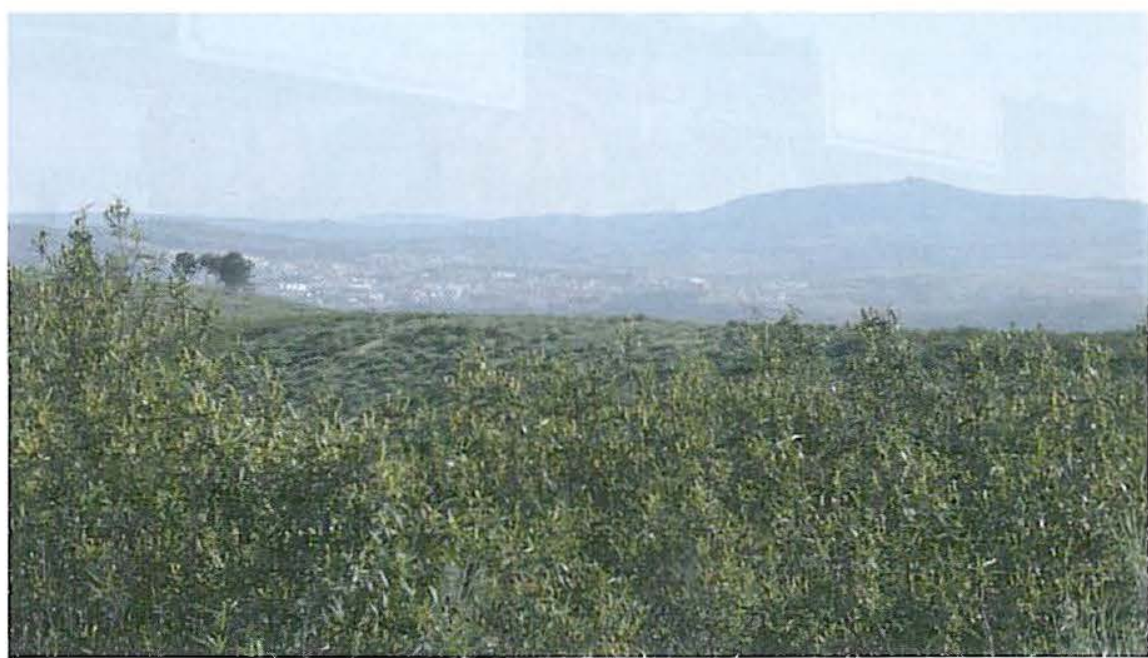

Shrubs - persistent elements in PNM landscapes, sign and challenge on land use sustainability: Cystus Indanifer near Aveleda, with Braganca urban area and Nogueira Mountain in farther plans (photo by $T$, de Figueiredo)

An unfortunate example of the difficulties involved in managing these kinds of systems is the system of indemnities or special hunting permitted to farmers that are affected by wildlife incursions into their crops. A few failures of this system have generated hostility against the Natural Park administration. Farmers also use traditional crop-protection methods, which can be improved. For example, some farmers hang large empty cans and a stick from trees. The wind moves the device, which acts as a simple noise-producing mechanism, keeping away wild boars and large wild herbivores. Some farmers put naphthalene in old cans, the smell of which protects vegetable gardens. Electric fences do not exist in the region but they could also be used, although seasonally rather than permanently, and also at the right time, so as to allow people and wildlife to move freely; this is essential to ecological processes (Alves, 2004).

In contrast, a very good example, to be regarded as best practice in rural development, is the promotion of local and protected rural products. In 1980, PNM staff started to organize yearly, in the first weekend of February, the Vinhais Fair of Smoked Sausage, which still continues. Local sausages contain chopped pork meat, seasoned with aromatic herbs or spices (pepper, red pepper, paprika, garlic, rosemary, thyme, cloves, ginger, nutmeg, etc.). Names like "Salpicão", "Alheira", "Linguiça", "Chouriço Verde", "Chouriça Boche", "Chouriço Doce", "Chouriço 
Pão", "Chouriço Chaviano", "Butelo", "Presunto", "Chispe", "Orelha" make up a very well developed list of highly profitable products. Currently, the principal agents of commercialization and promotion have been the Town Council of Vinhais and The National Association of Breeders of "Bísaro" pig. These bodies are now in charge of the organization of the Vinhais Fair, without any special need for PNM staff aid (IPB/ICN, 2006).

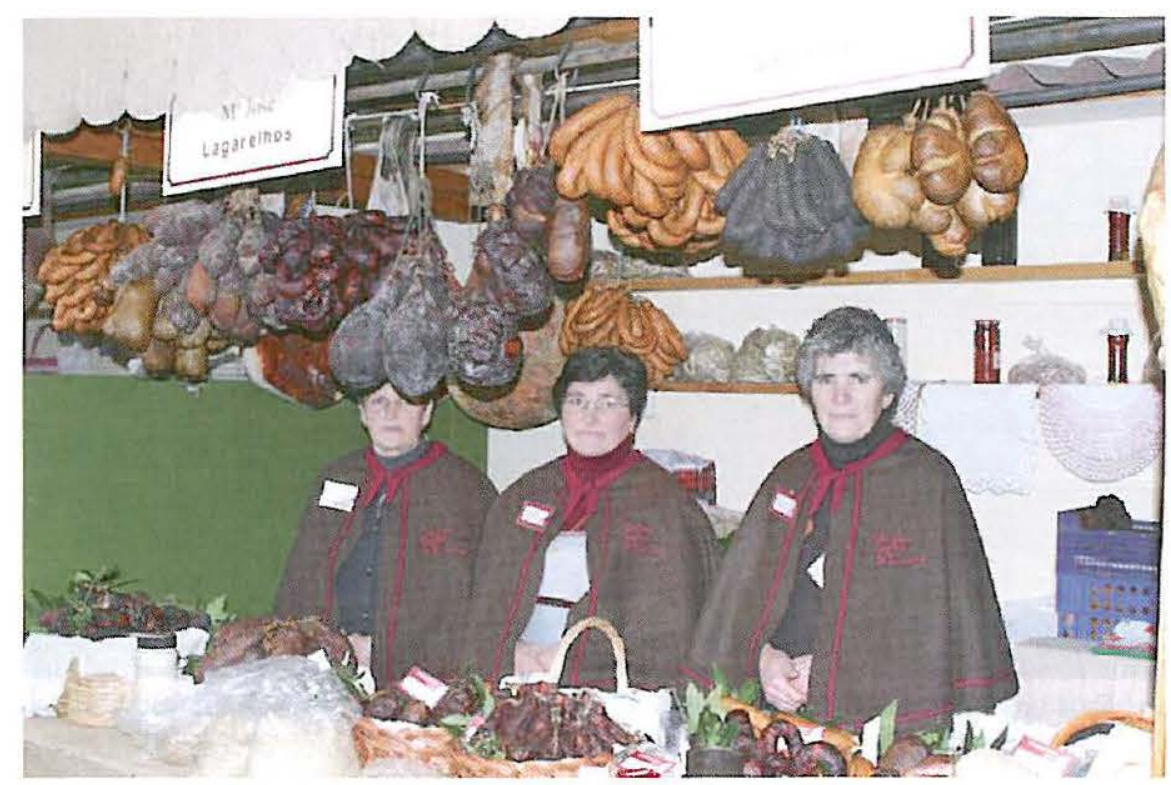

Vinhais Fair of Smoked Sausage - rural development in practice: exhibition of thewide variety of high quality traditional products in early February (photo by C.Alves, CM Vinhais)

\section{Photos By}

F. de Sousa, IPB / ESA, op324539j@mirandesa.pt

C. Alves, Câmara Municipal de Vinhais, carla.alves@cm-vinhais.pt

\section{References}

Alves, J. 2004. Man and wild boar: a study in Montesinho Natural Park. Portugal. In Galemys: Boletín informativo de la Sociedad Española para la conservación y estudio de los mamíferos 16(1): 223-230.

Pardo de Santayana, M., Tardio, J., Blanco, E., Carvalho, A.M., Lastra, J.J., San Miguel, E. \& Morales, R. 2007. Traditional knowledge of wild edible plants used in the northwest of the Iberian Peninsula (Spain and Portugal): a comparative study. In Journal of Ethnobiology and Ethnomedicine 3(27): 1-11.

IPB/ICN. 2006. Plano de Ordenamento do Parque Natural de Montesinho: I - Relatório de Caracterização. Bragança: Instituto Politécnico de Bragança. 